IRSTI 16.31 .02

\author{
Alkebayeva D.A. ${ }^{1}$, Amirov A.J. ${ }^{2}$, \\ Alimtayeva L.T. ${ }^{3}$, Kurmanzhanuly B. ${ }^{4}$, \\ ${ }^{1}$ Doctor of Science, Professor, ${ }^{2}$ Associate Professor, ${ }^{3}$ Associate Professor \\ of Al-Farabi Kazakh National University, Kazakhstan, Almaty, \\ ${ }^{4}$ Deputy Head of the Kazakh Language Department \\ of the of National Language Translations Center of CNR, CNR, Beijing, \\ e-mail: alkebaeva@mail.ru, abdibek71@mail.ru, lazalim72@mail.ru, berknur318@126.com
}

\title{
SPECIAL PURPOSE LANGUAGE
}

This article discusses the formation and development of a special purpose language that has recently appeared in linguistics. It is necessary to integrate the results of language research into the educational process of modern Kazakhstan into a special, purposeful, comprehensive, pragmatic intercultural communication that meets modern requirements. One of such directions is the special purpose language in Russian NCC, English (LSP). This article describes the reasons for the emergence of the language, the factors influencing it, its scientific and terminological character. Functional style of the special purpose language, its connection with the register, genre features, lexical units, conjugation of words, words from other language combinations, numerical and artificial symbols, terms of literary language, use of professional slang.

Key words: special purpose language, lexical units, conjugation of words, terms, numerical and artificial symbols.

\author{
Әлкебаева А.А. ${ }^{1}$, Әміров Ә.Ж. ${ }^{2}$, \\ Әлімтаева А.Т. ${ }^{3}$, Құрманжанұлы Б. ${ }^{4}$, \\ әл-Фараби атындағы Қазақ ұлттық университетінің 'профессоры, \\ ф. ғ. А., ${ }^{2}$ Аоценті, ф. ғ. к., ${ }^{3}$ Аоценті, ф. ғ. к., Қазақстан, Алматы қ. \\ ${ }^{4}$ ҚХР Ұлттар тіл-аударма орталығының Қазақ тіл бөлімі бастығының орынбасары, ҚХР, Пекин қ., \\ e-mail: alkebaeva@mail.ru , abdibek71@mail.ru, lazalim72@mail.ru, berknur318@126. com
}

\section{Арнаулы мақсатты тіл}

Бұл мақалада соңғы уақытта мингвистикада пайда болған арнаулы мақсаттағы тілдің қалыптасуы, дамуы қарастырылады. Заманауи талаптарға сай арнайы мақсатқа бағытталған, кешенді, прагматикалық, мәдениет аралық, коммуникацияда арнаулы мақсаттағы тіл зерттеулерінің нәтижелерін қазіргі Қазақстанның білім беретін үлерісіне қосу қажет. Сондай салалардың бірі арнаулы мақсаттағы тіл, орысшасы ЯСЦ, ағылшыншасы (LSP). Бұл мақалада арнаулы мақсаттағы тілдің пайда болу себептері, оған ықпал еткен факторлар, оның ғылыми-терминологиялық, сипаты туралы баяндалады. Арнаулы мақсаттағы тілдің функционалды стилі, регистрмен арақатынасы, жанрлық ерекшеліктері, ондағы лексикалық бірліктер, сөзжасамдық құбылыстар, басқа тілдің бірігуінен жасалынған сөздер, сандық және жасанды символдар, әдеби тілден жасалынған терминдер, кәсіби сленгтердің қолданылуы қарастырылады.

Түйін сөздер: арнаулы мақсаттағы тіл, мексикалық бірліктер, сөзжасамдық құбылыстар, терминдер, сандық, және жасанды символдар. 


\author{
Алкебаева А.А. ${ }^{1}$, Амиров А.Ж. ${ }^{2}$, \\ Алимтаева А.Т. ${ }^{3}$, Қурманжанулы Б. ${ }^{4}$, \\ ${ }^{1}$ А. ф. н. профессор, ${ }^{2}$ К. ф. н. Аоцент, ${ }^{3}$ К. ф. н. Аоцент \\ Казахского национального университета имени аль-Фараби, Казахстан, г. Алматы, \\ 4заместитель начальника отАела казахского языка Центра народных языковых переводов КНР, Китай, Пекин, \\ e-mail: alkebaeva@mail.ru, abdibek71@mail.ru, lazalim72@mail.ru, berknur318@126. com
}

\title{
Язык специальных целей
}

\begin{abstract}
В данной статье рассматривается фрормирование и развитие языка специального назначения, который в последнее время появился в мингвистике. Необходимо интегрировать результаты языковых исследований в образовательный процесс современного Казахстана в особую, целенаправленную, комплексную, прагматичную межкультурную коммуникацию, отвечающую современным требованиям. ОАним из таких направлений является язык специального назначения на русском языке NCC, английском (LSP). В статье описаны причины возникновения языка, факторы, влияющие на него, его научный и терминологический характер. Функциональный стиль языка специального назначения, его связь с регистром, жанровые особенности, лексические единицы, спряжение слов, слов из других языковых сочетаний, числовые и искусственные символы, термины литературного языка, использование профессионального сленга.

Кмючевые слова: язык специального назначения, лексические единицы, спряжение слов, термины, числовые и искусственные символы.
\end{abstract}

\section{Introduction}

The focus of linguists is the emergence of such spheres as language, language and culture, language of special purpose, and systematization of their scientific basis is essential for science.

In modern linguistics and methodical literature, the concept of language for special purposes has become widely used. P.Stevens, J.Svales, T.Hutchinson, A.Waters, Plekhan Alekseev, etc. p. (Stevens P.1977: 145, Svales J, 2004: 54, Hutchinson T., Waters A 1987: 65. Alexeyev PN, 1988: 62). In the works of these scientists, definitions, rules regarding the language of special purpose are considered in connection with the functional transformation of the language, and therefore provide a quality and effective communication in a particular area.

In the general scientific literature, scientific views on the structure and content of the language of special purpose, scientific-theoretical issues are different. In modern linguistics, scientific terminology, such as languages, interdisciplinary, functional styles, registers, and genres, which are closely related to a specific target language, can provide the structure and content of a language concept for specific purposes.

In order to achieve these goals, the following objectives must be achieved:

1) To study the history and development of the concept of special purpose language, to define its scope;

2) the special purpose language is used to compensate for the needs of the modern language of the consumer;
3) to determine the ratio of «special purpose language» in modern linguistics to «intercultural», «functional style», «register», «genre»;

4) analyze the business language in Kazakh and determine its results;

5) show the main scientific, methodological and general language aspects of the special purpose language for the Kazakh language.

All this leads to the need to communicate in intercultural communication to optimize special cultures, so it is necessary to learn a special language.

In the integration and accumulation structure you can use different text levels (words, phrases, phrases, super-economic units) and much more. An attempt is made to combine the results of the analysis. Special-purpose language has a text analysis methodology and rhetorical measures are also applied to a certain extent within the framework of cognitive and communication strategy.

The emergence and development of the concept of «special-purpose language» is closely related to the historical division of labor. "Language for special purposes» is a language designed to ensure mutually beneficial communication in a specialized and specialized subject in a generalized and concentrated language.

There are 3 dimensions for the language of the specialty:

1. Multidimensional internal format (subject area);

2. Functional style (scope of activity);

3. Relationship conditions; (participants of communication - owners of specialties). 
The latter criteria are stable, and the first two may differ depending on the degree of abstraction, and special vocabulary languages are used as linguistic tools of speech. In contrast to the special-purpose language, functional styles are conditional on one-dimensional subjects. The «special purpose language» is recommended for improving the communication of professional staff and then introduces an interdisciplinary concept that describes the general knowledge of the subject in the subject area for a certain level of abstraction and for the final goal.

Intensive development in modern society, society, technological changes and intercultural communication in different special places, the need for language-specific research and scientific concepts require. Therefore, it is also important to consider and develop areas of computer linguistics (computational linguistics) in this area, and there is great potential for this. The problem of specialpurpose language, which is a new field of modern linguistics, is an area specially considered for Kazakh linguistics.

\section{Experiment}

In modern linguistics, special-purpose language has long been studied. As required by different traditions, the use of the language for special purposes is socially and historically significant in terms of communication. Special-purpose language has been separated from the point of view of historical linguistic aspect. With the emergence of different divisions of labour, knowledge and concepts have been acquired in different professions. It has been the focus of the special knowledge language, it has acquired knowledge in various fields, and it has accumulated the language used by various scientific disciplines and its specialists, as well as the vocabulary of production and consumption. The concepts of «special purpose language» and «functional style», «register», "genre» in modern linguistics are interrelated.

The language of the special task is mainly communication, which provides spoken services in relation to the profession in relation to people. The concept of the special purpose language is composed of oral and written discourse in the form of text. They come from a variety of studies adapted to specific (professional) topics to address specific topics. A language text for special purposes is a text that is constantly compiled and accumulates a special knowledge base in which language units are stored.
In the second half of the twentieth century, special-purpose language has gone through new stages of its development. The special targeting language was used in English for international communication, technology, global communication in global trade and intercultural processes, i.e. to focus on a specific English language.

The process of internationalization and English philosophy in public life has often been a process. Its main reasons are international exchanges, international conferences, transnational research, international projects, consortia of enterprises and institutions, global scientific, industrial, educational processes and other types of Internet communications, e-mail, broadcasts in English, magazines published in English. L.S. Scherba's scientific discoveries have this problem. The functional peculiarities of the language in speech situations are analyzed. It consists of several stages

1. In the 1930 s, it was necessary to create an artificial language in a certain area,

2. The $50-60$ s of the 20th century depend on functional stylistics.

3. Depending on the mission of the English language.

The major initiative of this industry is closely related to the full English language's profound vision of the language of professional communication in 1962.

Both in Russia and abroad there are many variations of the term «language for special purposes». K.Y.Averbukh singles out the presence in German-speaking countries of the name Fachsprachen, in English-speaking countries - Languages for special (specific) purposes, in French-speaking industries: France medicale, France chemie, etc., which indicates the existence of their own names of the language of scientific communication in different countries. However, despite the ambiguous nature of the terminology, the need to recognize the language of science or language for special purposes has become apparent. «The first European symposium on «language for special purposes», i.e. the language used in various fields of human activity, such as medicine, law, education, etc., was convened in Vienna in 1977. (Averbukh, K.Ya. 2004: 215). A language for special purposes is a set of natural or natural-artificial language means, used in any field of knowledge and / or activity mainly for the transmission of subject information and reflecting the conceptual apparatus, which is not the property of the majority of native speakers of a given national language» (Khomutova T.N. 2007: 74). 
Special-purpose language is a language necessary for international communication. The emergence and development of the conceptual concept of language consists of the following three platforms: historical (pragmatic), linguistic and linguistic-hydraulic.

T. Hutchinson and A. Waterstars are based on two major historical events that influenced the special purpose language: 1) the end of World War II and 2) the oil crisis (Hutchinson T., Waters A., 1987: 87). Major historical events in the life of society have had a significant impact on the emergence and development of the special purpose language concept. The crisis of the 1970s and the unprecedented growth in scientific and technological development, economic activity and especially the need for English due to economic power, English becomes an international language, etc. E. The main factor in the formation of a special-purpose language.

Post-war development and post-crisis training required English as well as the language of specialization. English is not now an «art language for the arts», but the fate of English is devoted to the needs of people.

T. Hutchinson and A. According to Vaterer, the second factor in the language sector, which has the greatest impact on the development of special-purpose languages, is the major revolution. (Hutchinson T., Waters A., 1987: 55). In order to change the formal paradigm of the already established language science, it was necessary to pay attention to this problem. Linguists now need to focus on language learning for formal communication rather than for formal, languagespecific situational contexts. T. Hutchinson and A. According to Waterers, the third reason is related to the purpose of learning: firstly, language change has led to changes in communication, and secondly, to motivated learning and the need to meet the individual needs of the student to understand the need to change the content. In modern linguodidactics, special language theory is called personality theory.

In order to analyze the «special purpose language» experiment in modern linguistics, it was suggested that the concepts of «functional style», «register» and «genre» are closely interrelated. The experimental sample was formed from a special target language (O.A. Zyablova). 2005: 39, Kravtsova O.A., Yastrebova E.B. 2012, 30, Averbukh K. 2004: 92, Gwishiani N.S. 2013: 101, Moskalenko P.I. 2017: 328).

1. Functional style. Special purpose language» is a form of functional style, a new form. «Special- purpose language» and functional style are interpreted as one of the modern linguistic or other socially significant areas of communication and literary language, depending on the peculiarities of communication in this area. Depending on the nature of the functional style and relationships in different areas of human activity, the peculiarity of each style is the functionality of the language in this area. Functional style of language is directly connected with socially significant sphere of public speeches, in other words, sphere of dialogue and activity. Functionality of functional style depends on language function. The basis of functional style is divided into the following ones: 1) type(s), 2) activity of an individual (relations), determines the communication function of a person in the process of social speech communication, with the outside world, in the process of social interaction. Changes in social and industrial relations lead to changes in their speech, so today there is a variety of functional styles. Different styles interact with the classification of new functional styles. There are open systems with a central core and periphery (peripheral devices) of functional styles. The basic center of functional styles depends on language which is characteristic for the same style, and in extreme areas non-linguistic stylistic approaches are used. On the contrary, «Special-purpose language» is not limited to the thematic area of functional style and is intended for communication with professionals and non-experts in this area. The concept of «special purpose language» and the concept of «functional style» are common, and the communication function is the same.

2. The term «register» is associated with the name of M.Halliday (Halliday M.A. 1978: 16). This term is widely used in sociology, stylistics, «style of speech» in applied linguistics and to define the processes of change of function in the language. The register shows the functionality of the language in different situations. This term has undergone various changes in the development of structural and functional linguistics. The first meaning of the register is a typical text of typical lexical grammatical units. The register represents a functional type of language in different contexts. The register acts as an intermediary between the text and social context. It is characterized by three dimensions in each case (situational type) in relation to the actual value estimation:

- sphere - social sphere, subject area;

- social role of communication between participants;

- Normal role of language (jazz, verb, genre, literary and non-literary). 
A language function that serves three dimensions of the situation:

- a conceptual view of practice;

- social relations and interpersonal support;

- create a text text.

The register is a functional language, a semantic concept, a concept typical of specific concepts of the situation field. The concept of the register is sometimes directly related to the concept of «special purpose language». However, it should be noted that there is a radical difference between these concepts. The conceptual register is much broader than the «special target language». «Special-purpose language differs from language that is directly related to the use of human language, so that one can move to roles depending on the context of the speech act. R. This is usually seen in three P's: official, neutral and neophytic. R. Glazer identifies five typical numbers: 1) «Lady» (the only one on the top floor of the third floor); 2) official (Visitors to the museum should immediately climb to the second one); 3) trustworthy (don't worry, you can hang up on the third floor); 4) without inscriptions (Porsuk upside down); 5) «Intimate» (FAMILY) (Don't worry, guys!). 2. The same as the language subsystem (Glaser R.)

Register classification is a heterogeneous set of linguistic structures of business, legal, scientific and technical English language.

3. A special target language is considered a genre. The genre is a semiconductor semiconductor system with its own content and speech. The content plan or complex structure of the genre represents extreme factors, in particular, social actions, communication situations, participants and roles, activity, content of the topic. According to scientists, the special purpose language genre belongs to the type of oral and written text. Social context text, which is communicative and defined by certain formalities, is a new type of text. The American scientist J. Svales describes the genre as follows: «A common form of language unit genre, widely known to audiences in connection with the general profession of communicating with ordinary professionals» (Svales J. 2004: 54).

Definitions of modern linguistic genres are closely linked to sociolinguistic research, as the genre is seen as a form of sociolinguistic analysis. Genres are now changing in all fields of science.

A layout plan or language units corresponding to the entire structure, i.e. lexical, grammatical, stylistic, graphic, composite, etc. Д. Through language units the genre is formed in time and space. The concept of the genre corresponds to the level of discourse as a result of the use of linguistic multi-dimensionality.

The genre of special purpose corresponds to the characteristics of the register, as well as the compatibility of general language measurements directly related to the literary abilities of the language at each level of the special purpose language system.

4. Interlinear understanding. His appearance was the result of contact with people. They have to deal with a limited topic, even if they do not speak a foreign language, and use the most commonly used commercial languages. The multidisciplinary concept was used in the twentieth century to describe «special-purpose language» (e.g., the term «seafarers and lawyers»). Based on this explanation, in the Basic English language, which was created in the 1930s to facilitate the learning of a foreign language, Chapter Ogden teaches foreign languages. It has a limited set of 850 words and syntax rules. This concept has some intricate interweaving, which is usually a combination of foreign languages in higher education institutions, lawyers and metallurgists, so it is impossible to avoid mistakes in terminology, so the concept of special purpose language is a «functional style». «Register, Genre and Functional Diversity of Languages by different authors. There are ways. Currently, a foreign language is limited to the inter-lingual connection with the thematic range, which is interpreted as a set of lexical and grammatical structures.

\section{Result and discussion}

This article discusses the linguistic aspect of the special purpose language. Intensive growth of English business predetermines the growth and development of other components of the ASC (ESP). The analysis of genre, body and functional linguistics has had a great impact on the development of the ASC (ESP). The use of English as a means of interactive communication and interaction between non-English speaking speakers has a significant impact on various EAC (ESP) programs. Functional multilingualism, which, as mentioned above, ensures normal and effective communication of language specialties. The language of the special assignment itself is considered to be full of functional diversity, in particular limited research and communication. The Kazakh language is not yet fully understood and is still young. But it is time to write about the work in this field and the specialists who teach it. Most native English speakers (LSP) speak business English, and in Kazakh they are closely linked to the basic laws of the industry. For example, 
K.P.Chilingaryan describes the JCC for the Russian legal field (K.P.Chilingaryan 2014: 145-150). This law is characterized by the Kazakh language. The language of special targeting occurs with each level of the national literary language. Their heads can be described as follows. The most frequently used language units in the special purpose language genre are words from the general literary language, for example, in physics: «acceleration», «value» in the economy, etc.

Word processes from lexical elements of Latin and Greek languages. For example: aqua, hydro, etc;

- Hacking words from other languages:

- Digital and artificial symbols (in mathematics, genetics);

- terms developed on the basis of a common literary language (trial and error method, method of perversion and fraud in politics);

- professional slang; professional (speculator on the stock exchange), bruises (bruises);

- Brands and names. For example: aspirin, show and many other things.

Special-purpose languages are languages that are specifically limited (profession, profession, discipline, science) in a particular field of specialization. It will also provide additional tools to explain the low level of abstraction and specialization of professionals. For example, textbooks, teaching aids, teaching aids. At the same time, special knowledge can be obtained through certain axioms and truths (laws of energy conservation, law of attraction, transition from number to quality, etc.). Д.). This is why the interplanetary concept can be understood as a «special purpose language».

The «special purpose language» is in turn recommended for improving the communication of professional staff and then introduces an interdisciplinary concept that describes the general knowledge of the subject in the subject area for a certain level of abstraction and for the final goal.

Not all resources of all semantic and syntactic natural languages are fully used in all communication situations. This is why participants in communication create lexical and grammatically interdisciplinary interventions. In addition to the historical reasons, the method of individually oriented learning proves that linguistic development of special purpose takes place in two directions: linguistic and linguistic and waterdectic. On the one hand, it was connected with the functional study of the system-structural formation of the language, and on the other hand, it was connected with the method of teaching as a tool of special purpose language communication. That is why all linguistic or linguistic-hydrodactic researches of such scale are considered as functional grammar. This is a constant link between specialpurpose language as a form of linguistic and linguistic-hydrodactic research.

To create a special-purpose language, you must provide scientific literature relevant to the field. To create a «special purpose language» in the business field, you should refer to the relevant scientific literature. In Kazakh, TA Tasmagambetov, D.O. Belinov, «Accounting and Analysis» (2002), Z.A. Askarova, «Business Valuation» (2007), village Toksanbayev, «Dictionary of RussianKazakh Business Plates» (2008). This dictionary contains about 1500 words and phrases used by businessmen and brokers. T. Apuov, «Kazakh business» (2010); Abdilmanov, «Scientific and practical basis for the formation of a special industrial language» (2012); B. Makysheva, «Monetary circulation and credit» (2012) can be used (Tasmagambetov T.A., Abenov D.O., 2002, Askarova Z.A., 2007, Toksanbayev S., 2008, Apuov T., 2010, Abdilmanov A., 2012, Makyshev B., 2012).

The terms that rank first in the Special Purpose Language dictionary. Terminology is a set of names that serve to compensate for its communication needs by defining the system specificity of the concepts of a particular industry. Business terms derive from Latin, Greek, French, English, Italian and other terminology, depending on the development of business, development and stabilization of business, so include the Latin alphabet, rent (lease), deposit, earnings, mortgages from the Greek language, discounts (deductions) from English, know-how (francophone), force majeure (force majeure) are typical for all types of business.

Special-purpose language should be metatolized in each field of science. This also requires a scientific dissertation. Metallic is a specialized language. The main thing is to have terms from the national language dictionary. Let's look at the word «tax», which consists of one lexical unit. Tax breaks, tax system, tax rate, profit tax. The word «tax» refers to both pronunciation and verbal phrases, which complements the text content of the special purpose language. Taxation, taxation, taxation, taxation, taxation, tax stability, tax refunds.

According to Musagaliyeva, 60 per cent of business terms in Kazakh have the Kazakh equivalent, 15 per cent have been partially translated and 25 per cent have not been translated (Musagaliyeva A.K., 42).

Trading floor, market, barter, voucher, dealer, distributor, futures, leasing (commodity duties) 
in business. These include historical protectors, merchants, pajinas. For example, business exchanges are used in the special use language: allegri (lottery), gambling (sharp price changes), hawk (foreign wholesale carrier), roof (high price, high interest rates, high interest rates) Particle, project starting from scratch, bullish hour (steady growth in the stock market), bearish hour (steady decline in the stock market). Brief words: AIDA (enthusiasm, readiness to act), used in the preparation of the dealer, designer, KAF (cost and transportation), FOB (price at the airport), etc.

The terms «special purpose business language» should be described, amended, unified, standardized. Frequently used business terms are grouped in a central field, and its periphery is supplemented by rarely used terms. Business terms in Kazakh are semantically rich, structured and developed in accordance with the development process in society.

It should also be taken into account that the discussion in this area is different. Thus, lexical and grammatical limitations limited to communication are considered part of a special purpose language that uses artificially modelled means of communication, with the aim of investing in the process of communication in a language that describes a specific subject area and in the teaching of a foreign language for specific purposes. Registration has three levels: informal, formal and neutral. Less or less free to choose a language tool (informal or neutral) when communicating with one person in the same social environment; when communicating with strangers, language tools are chosen - supporting the language repertoire (e.g. communicating with an employee, doctor or judge, avoiding verbal abuse, usually advocating for verbal behaviour). Language is a means of communication and a method of learning. Knowledge is the answer to an action that strikes the mind and results in a result.

Each function explains the potential meanings of this type of situation. Each of the potential values in this situation speaks only about some of them. In this case, the set of treaties is a concept that ensures the continuity of the text and its continuity between the social and semiotic environment. By analyzing the careful selection of grammatical and lexical units in a special text, we can define the composition and restore the social situation.

\section{Inference}

After all, a specialty language is a new field of study. The industry has its own history of development, prerequisites and scientific and theoretical basis. The special-purpose language industry has not been formed at once. The first foundation of this industry began to be formed from the division of labour. This was due to the need for English language skills, the results of international communication and communication, and the demand for various professions. For example, language courses for special purposes can also be found in Russia (http: prosv.ru).

As a result of scientific researches of scientists in the field of foreign linguistics there appeared. The language of special targeting is an area with specific features, although it is closely related to the spheres of «functional style», «register» and «genre». This is why this field is closely related to such areas as genre types, functional style, computer linguistics, and speech communication. These lexical and grammatical units of linguistics, as well as certain communicative dimensions have special vocabulary terms, and the relevance of this industry research is in demand by the public. Register is a multidimensional concept, which is a unit of language specification at the level of discourse. A multivariate combination that describes a language at the speech level is used to describe the discourse in a three-dimensional system. This, in turn, includes numbers such as subtitle language and measurement functional style such as genre and communication.

«Special-purpose language», in turn, is a very important area of communication for professionals and professional contacts in this field. Specialpurpose language is communication that provides speaking services in relation to a particular profession in the face of people. The special task language is written in the form of an oral and written speech. This is the type of text that is created on specific (professional) topics to talk to a specific professional speaking service.

This requires that modern intercultural communication be considered as scientific concepts and special linguistic areas of the special language, so it is also important to develop and improve the special language, which has great potential. 


\section{Әдебиеттер}

Strevens P. Special purpose language learning: A perspective // Language Teaching and Linguistics Abstracts. - 1977. - N 10. - P. 145-163.

Гвишиани Н. Б. Язык научного общения (вопросы методологии). - М., 1986. - С. 219.

Swales J. M. Research Genres. Explorations and Applications. - Cambridge: Cambridge University Press, 2004. - P. 54.

Hutchinson T., Waters A. English for Specific Purposes: A learning-centered approach. - Cambridge: Cambridge University Press, 1987.

Алексеев П.М. Частотные словари и приемы их составления // Статистика речи. Отдельный оттиск. - Л., 1968. - С. 62. Авербух К.Я. Общая теория термина. - Иваново, 2004. - 252 с.

Хомутова Т.Н. К вопросу типологии функциональных стилей // Актуальные вопросы современного университетского образования: Материалы X Российского-Американской научно-практической конференции 14-16 мая 2007 года. - СПб. C. $296-300$.

Зяблова О. А. Принципы исследования языка для специальных целей: Дис. ... д-ра филол. наук. - М., 2005. - С. 314.

Кравцова О.А., Ястребова Е.Б. Английский язык для специальных и академических целей. Международные отношения и зарубежное регионоведение: Учебное пособие. В 2 частях. Часть 2. Уровень С1. Ч. 2. - М., 2016. - С. 231.

Гвишиани Н.Б. Язык научного общения: Вопросы методологии. - М.: ЛКИ, 2013. - С. 280.

Москаленко П.И. К вопросу о понятии «язык для специальных целей» и термине, его обозначающем // Молодой ученый. - 2017. - №19. - С. 410-414.

Halliday M. A. Language as Social Semiotic. - London: Edward Arnold, 1978. - P. 145.

Чилингарян К.П. Английский для специальных (АСЦ) целей в современном обществе // Международный журнал экспериментального образования. - 2014. - № 3-1. - С. 145-150.

Тасмағамбетов Т.А., Әбленов Д.О. Бизнес есеп пен талдау. - Алматы, 2002.

Асқарова Ж.А. Бизнесті бағалау. - Алматы: Заң әдебиеті, 2007. - 194 б.

Тоқсанбаев С. Орысша - қазақша бизнес - биржа жаргондарының сөздігі. - Алматы: КИЕлингвоелтану инновациялық орталығы, 2008. - 200 б.

Апуов Т. Қазақша бизнес. - Алматы, 2010.

Әбділманов А. Арнаулы сала тілін қалыптастырудың ғылыми-практикалық негіздері. - Алматы, 2012.

Мақышев Б. Ақша айналысы және несие. - Алматы: Қазақ университеті, 2012.

Мусағалиева А. К. Қазақ тілінде бизнес терминдерінің даму үрдісі. - Алматы, 2014.

\section{References}

Abdylmanov A. (2012) Scientific and Practical Basics of Formation of a Special Industrial Language. Almaty. 2012. 217 p. Alexei P. M. (1968) Frequency Dictionaries and Techniques and Status [Statistics of Statistics]. Separate socket. Л., 1968. 62 p. Apulov T. (2010) English business. Almaty. 2010. 159 p.

Askarova Z.A. (2007) Business assessment. Almaty: Legal Literature. 2007. 194 p.

Averbukh, K.Y. (2004) General theory of thermography. Ivanovo. 2004. 252 p.

Chilingaryan K.P. (2014) English for special purposes in modern society [International Journal of Experimental Education].

2014. № 3-1. 165 p.

Gvaniyani N. B. (2013) Language of Science: Methodological Problems. LKI. 2013. 280 p.

Hutchinson T., Waters A. (1987) English for Specific Purposes: A learning-centered approach. Cambridge: Cambridge University Press. 1987. 198 p.

Khalliday M. A. (1978) Language as a social semiotic. London: Edward Arnold. 1978. 145 p.

Khomutova T.N. (2007) Functional and stylistic typologies [Topical issues of modern university education: Proceedings of the X Russian-American scientific-practical conference on May 14-16]. Saint-Petersburg. 2007. 354 p.

Kravtsova O.A., Yastrebova E.B. (2016) English for special and academic purposes. International relations and foreign regional studies. Textbook. In 2 parts. Part 2. Level C1. Chapter 2. M.: Nauka. 2016. 231 p.

Makyshev B. (2012) Management and credit. Almaty: Kazakh University. 2012. 194 p.

Moskalenko P. I. (2017) To the question of the concept of «young scientist. 2017. №19. 456 p.

Musagaliyeva A.K. (2014) Process of development of business terminals in Kazakh language. Almaty. 2014. 126 p.

Strevens P. (1977) Special purpose language learning: A perspective [Language Teaching and Linguistics Abstracts]. 1977. N 10.215 p.

Swales J. M. (2004) Research Genres. Explorations and Applications. Cambridge: Cambridge University Press. 2004. 54 p.

Tasmagambetov T.A., Abilenov A. (2002) Business reporting and analysis. Almaty. 2002. 128 p.

Toksanbayev S. (2008) Dictionary of Russian-Kazakh business - stock compounds. Almaty: Innovation Center of Independent Sciences. 2008. 200 p.

Zyablova O. A. (2005) Principles of language research for special purposes. Disk ... Dr. Philol. Science. M.: Nauka. 2005. 314 p. 